\title{
Pro-Social Trickstars in Khaled Hosseini's A Thousand Splendid Suns
}

PAUL RÜSSE

ANASTASSIA KRASNOVA

\begin{abstract}
Abstrac. Tricksters are usually defined as non-heroic male characters obsessed with food, sex, and general merrymaking, occasionally changing shape and even gender but eventually returning to their masculine self. But is this necessarily true in contemporary ethnic literature? The current essay explores the notion of the trickstar, or the female trickster, in AfghanAmerican fiction, analysing the three heroines in Khaled Hosseini's 2007 novel A Thousand Splendid Suns, which is a mother-daughter story set in Kabul at the turn of the millennium. In order to place this text into a cultural context and underscore the significance of the trickstar figure, it is compared to a traditional Afghan folk tale, "Women's Tricks." Two research questions are at the centre of this article: (1) In what ways are trickstars from Afghan folklore similar to the heroines of Hosseini's novel? and (2) What roles do his heroines perform as pro-social trickstars?
\end{abstract}

Keywords: American literature; Afghan folklore; tricksters; trickstars; Islamic feminism

The theory of the Collective Unconscious, which is populated by instincts and archetypes, was developed by Carl Gustav Jung. According to it, "archetypes are typical modes of apprehension, and wherever we meet with uniform and regularly recurring modes of apprehension we are dealing with an archetype, no matter whether its mythological character is recognized or not" (1970: 13738). One of his archetypes is the trickster, who is a "faithful reflection of an absolutely undifferentiated human consciousness, corresponding to a psyche that has hardly left the animal level" (1981: 260). The trickster archetype's characteristics are the ability to change the shape and to trick others, often due to some unconscious or secret knowledge (1981:256).

The trickster archetype "haunts the mythology of all ages" (Jung 1981:260) and its presence in the mythology of various countries has been researched. For instance, Paul Radin's The Trickster discusses the trickster in the Winnebago myth cycle and defines him as a "creator and destroyer, giver and negator, 
he who dupes others and who is always duped himself. [...] He possesses no values, moral or social, is at the mercy of his passions and appetites, yet through his actions all values come into being" (1956: xxiii). Lewis Hyde in his book Trickster Makes This World (1998) examines tricksters in various countries and cultures and their effect on contemporary art. He states that "in short, trickster is a boundary-crosser" and at the same time he "creates a boundary, or brings to the surface a distinction previously hidden from sight” (1998: 15-16).

It is evident that the topic of tricksters has been researched thoroughly, especially their role in Native American and African American literature. The figure of the female trickster, or trickstar, however, has not been so widely examined. Marilyn Jurich in Scheherazade's Sisters claims that the trickstar is a distinct type of the folktale character. Trickstars save themselves as well as other people, pursue their goals and change the reality through their tricks (Jurich 1998: xvii). Maria Tatar in The Cambridge Companion to Fairy Tales further discusses the female trickster as a separate archetypal character and argues that Jurich, by focusing on trickery, impoverishes the notion of the trickstar.

In her TED talk "A Theory of Everything”, Emily Levine identifies herself with a trickster and suggests that the majority of the audience share the same traits because "what trickster is is an agent of change" (2012: 13:39-13:45). She claims that the qualities of the trickster that make the change possible are boundary crossing, non-oppositional strategies, "smart luck," "having a poise" and "being always on the road" (2012: 13:48-22:33). TED's media production specialist, Angela Cheng, defines the trickster as "anybody who's a bit of an outsider." She says that as a result of living outside the rules, tricksters are able to change these rules.

\section{Trickstars}

Most of research conducted on tricksters focuses on the male trickster and sees the female transformer as one of his guises. Lewis Hyde acknowledges that there are women who perform tricks both in the real world and in the mythology. However, he believes that they do not fully match the definition of the trickster. They either lack "the elaborated career of deceit that tricksters have" or, like a Female Coyote found among the Hopi and the Tewa Pueblo Indians, function "alongside a more traditional male Coyote." Hyde explains that this is due to the fact that tricksters operate in patriarchal societies, "and it would seem that patriarchy's prime actors, even at the margins, are male" (1998: 17). 
RÜSSE, KRASNOVA

Hyde is partially right and female tricksters indeed do not match the traditional definition of the trickster, but only because it is applicable only to male tricksters. Female tricksters, however, need to be defined separately. Marilyn Jurich was the first to define female tricksters and to call them trickstars. As a result of being oppressed, being denied the basic human rights, and powerless throughout history, women needed a way to survive and to get what they want. Women needed to gain power, and "the powerless have only the trick as their resource" (1998: xvii). Thus, they had to become "'stars' in trickery" (1998: xiv).

Through analysing tales from various countries and nations, Jurich discovered the existence of an archetypal trickstar character. The best-known trickstar is probably Scheherazade, who saves the women of Baghdad through a wisely chosen tactic. Scheherazade tricks her husband not to gain power but to protect herself and others. She strives to bring order, to protect the vulnerable, and to provide a safe environment. "While Scheherazade tells her story, she is her own story. She is a trickstar, one who slyly conceals her motives from the individual she means to use or transform" (Jurich 1998: xvii). To find the trickstar among other archetypal female characters, we need to look for indirection. "Through 'slant' [...], through shadow and innuendo, muted tone and meaningful pause, we come upon her" (Jurich 1998: 18). To understand the trickstar one needs to understand what embodies the trick.

Trick by its very nature is left (sinister or devious), rather than right (straight or direct), truthful, on the level. Its natural connection, then, seems to be with the diabolical, for evil is dark and secret and takes us unprepared. (Jurich 1998: 2)

Historically, women have the same associations: they are stereotypically seen as wicked, cunning, and indirect. Thus, the essence of trick is strengthened when combined with the personality of the trickstar (Jurich 1998: 3). The tricks of women differ from those of men. Women "usually depend on their sexuality and their knowledge of sexuality - both men's and women's." The power of the woman lies not in material property, physical strength or military force, but "in her disposition and in her brain" (Jurich 1998: 19).

Another notion that needs to be mentioned is the idea of deceit:

Deceit has less to do with truth or falsehood than with enactment of an illusionary relationship; [...] illusionary relationships involve legitimate assertions of personal difference and of independence of society. (Basso 1987: 3) 
This explains the need for the trickstar to conduct deceit. Her identity is the one that needs to be established and secured in society. Trickstar resorts to deceit to find her way in folktales, in the Bible, and in classical literature (Jurich 1998: 33).

The female trickstar remains hopeful and practical in the most complicated circumstances. She is a remarkable example of a female using her sense of humour to create new possibilities, to inform and create awareness:

Humor is a way of coping and also a subversive force, a means of helping us to survive inequity and injustice as we expose and criticise oppressive conditions and systems. For all these reasons, humor serves women and often serves them even better than it does men. (Jurich 1998: 24)

Trickstar is a "culture-bringer" (Jurich 1999: 31). She is opposed to the existing social order and fights to derogate the power of the highest levels of society and to improve the lives of the lowest. Due to this, she is "perceived as a threat" and "treated as an outcast, even a scapegoat" (Jurich 1998: 33). This leads to another characteristic of the trickstar - marginality. "They are the lords of inbetween" (Hyde 1998: 14). Marginality is even more expressed in the trickstar than in the trickster: "Woman by virtue of gender alone has been marginalized; and trickstar is a twice-marginal figure" (Jurich 1998: 34). Furthermore, the trickstar consciously uses her marginality. Men do not expect a woman to be able to trick them, to make a change, or to improve society - and this gives an advantage to the trickstar.

Maria Tatar adds one more quality of the trickstar to the list. It is the "notion of female tricksters as double agents, women who operate using strategies both subversive and transformative in order to construct their own identities but also to effect social change" (2014: 46). This quality refers to the ability of the trickstar to make her way even while serving others.

The main difference between the trickstar and the female hero is that the latter is rescued at some point of the story. The trickstar, however, is herself the rescuer:

The woman trickster in folktales is not the Princess on the Glass Mountain or Sleeping Beauty among the briars or Snow White in her coffin - not any of these numerous maidens imprisoned in towers or inside of caves where they are set upon by dragons. Rather, it is the trickstar heroine who rescues her lover, her husband, and other deserving (and undeserving) individuals; and when she herself is in difficulty, chooses and manages her own escape route. (Jurich 1998: 23) 
RÜSSE, KRASNOVA

The most apt definition of female tricksters, however, can be found in Lori Landay's monograph on con women in American culture. She lists such typical tactics as "deception, disguise, duplicity, subversion, feigned simulation, parody, and impersonation" in combination with specifically "female practices such as the use of makeup, sex appeal, emotional manipulation, and exploitation of the inconsistencies of the sex-gender system" (1998: 30).

\section{Tricksterism in Afghan Folklore}

Afghan oral literature had been extensively influenced by Persian culture and literature. Classical Persian literature is "a common heritage of the peoples of Iran, Afghanistan and Central Asia (Tajiks)” (Ioannesyan 2009: x). Nowadays Afghanistan has two official languages: Pashto and Farsi (Afghan Persian), which has its origins in Old Persian. Since 1958, Farsi has also been known as Dari (Olesen 1995: 205).

Tajik, Dari and Persian are "languages" in the sense that they have concretized canonical forms that are transmitted through institutionalized schooling and reference works, however structurally they are all varieties of Persian. (Bee$\operatorname{man} 2005: 3$ )

One Thousand and One Nights presents the story of the most famous trickstar figure - Scheherazade. Although there is no certain answer to the origin of this tale, one of the most convincing theories is that its roots are in Persian literature. For example, Richard Burton, the author of the celebrated translation of One Thousand and One Nights into English, "argued that the original core of the stories had come into the Arab lands from Persia” (Irwin 2003: 45). It is possible that the book from pre-Islamic Sasanian Persia was translated into Arabic in the eighth or early ninth century and was given the name Alf Layla (Irwin 2003: 49-51). It is possible to conclude that trickstar tales appeared in Persian literature already as early as the $3 \mathrm{rd}-7$ th century, when Persia was ruled by the Sasanians (Pourshariati 2008: 1).

In Islamic literature and tradition, the theme of women's tricks is exceptionally popular. Persian idiomatic expressions feature women who are cunning and deceptive. The Afghan proverb "Women are seven steps ahead of the devil" (Mills 2011: 63) serves as an example of women being perceived as more devious creatures than the devil itself. The trickery of women can also

Arabic: A Thousand Nights. 
be found in the Qur'an in the story of prophet Yusuf in Egypt. Yusuf escapes from the attempted seduction by his master's wife. The wife tries to cover her guilt by blaming Yusuf. When her lie is discovered, her husband says: indeed, it is of the guile of you (fem. plural). Indeed, your (fem. plural) guile is great (Qur'an, Yusuf 12:28). As a result of seeing trickery as part of women's nature, the trickstar is widespread as a folktale character.

Margaret Mills recorded numerous Dari Persian folktales in the 1970s with both male and female tricksters. They appear as principal or supporting characters and can be both heroes and villains. However, tricksterism in males appears merely as the quality of that character type (2011: 62).

The problem with the representation of trickstars in Persian and, more specifically, in Afghan folktales is that they create a negative stereotype. "The word makarah ('trickster,' feminine noun) is synonymous with 'adulterous woman' in everyday speech" (Mills 2011: 63). The goal of these trickstars is usually materialistic gain or the simple amusement of committing a mischief. However, the general view on the trickstar in Afghanistan is not always negative. In oral tradition, according to Mills, both men and women tell stories with prosocial trickstars, i.e. "women who employ tricks in order to secure justice and repair social order, including patriarchal sexual and family order, normally in the hands of men" (2011: 64). They usually act as social revolutionaries when male authorities fail. Because women are natural tricksters, men cannot see what they intend to do and cannot defend themselves from being tricked:

Guile (makr, kayd) or trickery can be categorized as a weapon of the weak, and thus quintessentially of women. There is an abundance of male tricksters as well, and not all of them are underdogs, but a trickster in a position of power or acting on behalf of the power elite (e.g., an evil vizier and/or his old-woman accomplice) is inevitably the one who loses to the less socially powerful hero or heroine. (Mills 2001: 240)

The trickstar is often presented as a sexually ravenous woman, a seductress. Even though some of the trickstars match this description, more often than not the trickstar is a woman who simply desires to receive sexual satisfaction from the man she chooses herself. Women are often prohibited to choose a husband for themselves and depend on the decisions of their parents. Therefore, they become trickstars. The trickstar sometimes chooses to avoid sex; in other cases, she decides to be with a man of her choice and does everything to accomplish this (Jurich 1998: 30).

A common feature of Afghan folktale trickstars is that, although they easily trick men, transform society, and restore peace, the result of their actions is 
RÜSSE, KRASNOVA

the reestablishment of patriarchal authority that respects women. Mills, when discussing the nameless heroine of the folktale "Women's Tricks," told by Shahbubu Ghafoury, says, "This pro-social woman trickster is no simple revolutionary, however; her agency is highly conservative in this as in other such stories, directed to upholding patriarchy in the face of men's inability to do so" (2011: 67). The trickstar resists and exposes the hypocrisy of male authorities and at the same time "she may protect the interests of males who are not themselves exploitative hypocrites" (Mills 2012: 280).

In Afghanistan, the home is definitely a woman's territory, even though men attempt to control it: "Domestic space in the tale world is not the space of secluded control of females, as patriarchal values would idealize it, but of female control and subversive activities" (Mills 2012: 283). This makes home an ideal territory for the trickstar to perform her tricks.

\section{“Women's Tricks" as a Female Trickster Story}

What follows is a discussion of the female characters of Hosseini's book $A$ Thousand Splendid Suns and an attempt to establish whether these characters embody distinctive traits of the folktale trickstar. The folklorist Margaret Mills has recorded several oral Afghan tales, one of which is taken as an example of an Afghan trickstar tale.

Oral tales have been chosen because they are prevalent in Afghan society, which, even nowadays, "remains a primarily oral society" (Mills 2011: 60). The reason for that is the fact that the majority of the population is illiterate. For males, the literacy rate was around 40 percent in 2009, but education for women and girls was still hardly available and their literacy rate was no more than half of the male one (Mills 2011: 54). It is then highly probable that Hosseini, who spent his childhood in Afghanistan, has been influenced by traditional oral tales. Furthermore, Hosseini visited Afghanistan as a writer in the spring of 2003, and this visit inspired him to write his second novel, A Thousand Splendid Suns. In an interview he said, "Though no one woman that I met in Kabul inspired either Laila or Mariam, their voices, faces, and their incredible stories of survival were always with me, and a good part of my inspiration for this novel came from their collective spirit" (2003). This highlights the significance of traditional storytelling and the influence it has had on Hosseini's novel.

The folktale which serves as an example to determine the features of the Afghan trickstar is called "Women's Tricks" and is taken from the chapter "Destroying Patriarchy to Save It: Safdár Tavakkolís Afghan Boxwoman," written by Margaret Mills. It is a traditional Afghan folktale about a trickstar 
who forces her oppressor (or oppressors) to hide in a trunk or other type of box. This theme is common in trickstar tales throughout the world and can be found in the tale "A Lady and Her Five Suitors" from One Thousand and One Nights (Burton 1968: 101-106).

The story analysed here was told by Safdár Tavakkolí, a "renowned twentieth-century Afghan male storyteller" (Mills 2012: 279). The audience consisted of several male listeners and the recording was given to Mills for a book project about Afghan trickstars by Ravshan Rahmoni, "the Tajik folklorist” (Mills 2010: 308).

It is the story of a mullah who decides to write a book called Wiles of Women or Women's Tricks and goes around watching women and writing down their tricks. One time, while he is sitting and watching women do some work, one of the women notices him and demands that he explain why he is watching them. After he tells them that he writes down women's tricks and brags about his knowledge of women and all the tricks they have, the woman invites him to her house for some tea where she tricks him and makes him swear that he will never write about women's tricks and will never even mention them. At the same time she manages to trick her husband and win a wager she had with him.

The woman in this story has several qualities of the trickstar and can serve as an example of an Afghan trickstar in traditional storytelling. To begin with, the reason for the trickstar's actions is the unqualified and arrogant attempt of the mullah to write a book about women. The story starts with explaining that the mullah has "read a few pages, bits of a book" and thought himself educated enough to write his own book. Furthermore, the mullah is an example of an ignorant and chauvinistic male. He believes himself superior to women and thinks he knows them better than the women themselves do:

Well, I've got women's tricks right in my pocket! I know you've got this kind of tricks, and that one has that kind of tricks, and that other one has that other kind - this kind of tactics and tricks, that other one has that other kinds of skills and arts; [...] short women are like this, tall ones are like that, the tancolored ones are like so and the pale ones are like so and the yellowish ones are like so. (Mills 2012: 285)

The mullah is so overconfident that he does not suspect anything when the trickstar invites him for tea after his speech. He takes her attention and interest as a logical reaction because he is convinced that she admires his intelligence. To resist and uncover the bigotry and incompetence of males is one of the motives of Afghan trickstars. 
RÜSSE, KRASNOVA

“The Afghan home is specifically the women's realm, with male authority only attempting to control it from without” (Mills 2012: 283). The trickstar in this tale invites the mullah to her house, as this is the place where she has the most power. In patriarchal societies like Afghanistan, males have all the power outside the house and do not participate in house management, leaving it to women. This makes domestic space a place of power for women, and a territory for the trickstar to perform her tricks. The tale also shows the conflict between the trickstar and her husband, who wants to dominate the domestic space: "they wagered for who would have the 'say,' the authority in the house" (Mills 2012: 285-86). The trickstar, therefore, tricks her husband in order to win the wager and to force the husband to acknowledge her power in the house. Finally, he submits that she has "got the 'say' in this house" (Mills 2012: 288).

The trickstars are notorious for using their feminine powers to control men. The trickstar in this Afghan folktale uses this tactic several times. Firstly, when she and the mullah enter the house, she starts playing with his pride, serving him as if he were an honourable guest, and doing other small things for his comfort. Then, after serving the food, she decides to arouse passion in him. She sits down to eat with him, even though this act goes against the rules of hospitality: "Sitting down to eat together, especially for a woman with a man, is an intimate or seductive act” (Mills 2012: 291). The trickstar goes even further as "she makes up a mouthful with her fingers and holds it close to the mullah's mouth". At this point, mullah is already having sinful thoughts, so he takes food from her fingers and, as the storyteller says, he "gets hot - and he's just quivering" (Mills 2012: 286). The mullah copies the trickstar's action and offers her food in his hand, which she accepts. This scene demonstrates the power of the trickstar to influence men through their sexual desires and her decision to break the rules to fulfil her aim.

Trickster tales "tend to be full of scatological and sexual humor" (Nicholas 2009: 9). In trickstar tales, scatological humour is less prominent but is still used occasionally. In this case, for instance, it is used to further humiliate the mullah. When the trickstar's husband returns and the mullah is hiding in the trunk, she starts to tell the husband about the boyfriend she is hiding there and the mullah becomes scared. The narrator says that "the mullah, right there, now, his ass is beginning to stink [laughs], he's losing it altogether, right then he fouled his pants, and inside the trunk it starts to stink" (Mills 2012: 287). This continues later in the tale, when the husband goes back to work and the trickstar opens the trunk to release the mullah she asks him, "Are you dead? Since when - last year?” (Mills 2012: 289). When the mullah leaves the trunk, 
he is dirty, stinking, and completely helpless. The trickstar makes him repent and promise to never mention women's tricks.

The final result of the Afghan trickstar's actions is the recovery of patriarchal society or at least a public semblance of it. The trickstar shows her power to dominate and change the social order, but in the end she transforms the reality to save the patriarchal order. In this tale, the trickstar gets the authority in the house, but the husband remains the nominal head of the family. She tricks the husband to win the wager, but at the same time she remains faithful to him and punishes the mullah, who wished to seduce her. Therefore, the misbehaving mullah is disciplined, the authority in the house is the woman's, and patriarchy is restored in a corrected form, thus corresponding to the main principles of Islamic feminism, which is based on the Qur'an.

\section{Three Trickstars in A Thousand Splendid Suns}

Nana. The trickery in A Thousand Splendid Suns begins with Nana, Mariam's mother. Nana lives with Mariam in a $k o l b a^{2}$ in the clearing on the outskirts of Gul Daman village. It is hard to approach their house:

To get to it, one took a rutted, uphill dirt track that branched off the main road between Herat and Gul Daman. [...] The path ended perpendicular to a wide, trout-filled stream. [...] Two hundred yards upstream, toward the mountains, there was a circular grove of weeping willow trees. In the center, in the shade of the willows, was the clearing. (Hosseini 2008: 9)

The location of their house makes both Nana and Mariam isolated from the world and puts them into an ideal place for the trickstar: marginal and on the outskirts of society. Nana is isolated not only because of her environment but also due to her social status. She is thought to be possessed by a jinn ${ }^{3}$ although in reality she probably has epilepsy:

Nana collapsing suddenly, her body tightening, becoming rigid, her eyes rolling back, her arms and legs shaking as if something was throttling her from the inside, the froth at the corners of the mouth, white, sometimes pink with blood. Then the drowsiness, the frightening disorientation, the incoherent mumbling. (Hosseini 2008: 10)

2 Farsi: hut, dwelling.

3 A supernatural creature in Islamic mythology. 
RÜSSE, KRASNOVA

The illness makes people afraid of her, as they do not understand the nature of it. Her fiancé calls off the wedding, and no more suitors have the courage to propose to her.

Nana's social isolation intensifies when she becomes pregnant by her employee Jalil. Her father disowns her and disappears because he cannot do what was expected of him in this situation. Nana tells Mariam that her father did not have "a stomach to sharpen one of his knives and do the honourable thing" (Hosseini 2008: 6). She adds that Jalil did not have a heart to do the "honourable thing" either: he did not have the courage to "stand up to his family, to his wives and in-laws, and accept responsibility for what he had done" (Hosseini 2008: 7). Instead, Jalil quickly sends her away.

Another trickstar trait present in Nana is the ability to uncover the bigotry of authoritative males. While Mariam is infatuated with her father, Jalil, Nana tries to warn her not to believe everything he says and tries to uncover his true self. When Jalil tells Mariam about a pistachio tree in Herat and says that he took her there when she was little, Nana accuses him of lies: "Rich man telling rich lies. He never took you to any tree. And don't let him charm you. He betrayed us, your beloved father" (Hosseini 2008: 5). Nana attempts to show Mariam the injustice of her life. In response to Jalil telling Mariam about children getting free ice cream in his cinema Nana says, "The children of strangers get ice cream. What do you get, Mariam? Stories of ice cream” (Hosseini 2008: 6). In addition to revealing Jalil's bigotry, Nana uncovers the bigotry of prejudiced men in general. She discloses to Mariam that Jalil, to defend himself before his wives, told them that Nana had forced herself on him. He laid all the blame on her. Then she explains the fate of the woman in this world to Mariam: "Learn this now and learn it well, my daughter: Like a compass needle that points north, a man's accusing finger always finds a woman. Always” (Hosseini 2008: 7). Later, these words would become the guiding principle of Mariam's entire life.

According to Hynes, "the trick-playing of the trickster clearly distinguishes itself from other forms of trickery by its frequent association with shapeshifting and situation-inversion" (1993: 36). Nana's shapeshifting is expressed through her appearance and behaviour change in the presence of Jalil. On Thursday, Jalil visits the kolba and Nana attempts to look good for him. Her hair is washed, her teeth are brushed, and she wears her best hijab ${ }^{4}$.

She sat quietly on a chair across from him, hands folded on her lap. She did not look at him directly and never used coarse language around him. When she

4 Headscarf. 
Pro-Social Trickstars in Khaled Hosseini's A Thousand Splendid Suns

laughed, she covered her mouth with a fist to hide the bad tooth. (Hosseini 2008: 22)

This quiet and civilized manner stands in contrast with Nana's behaviour towards Jalil's sons. On Ration Day, when the boys bring food and basic necessities to the kolba, Nana insults them and their family and throws rocks at them. Even her appearance changes dramatically:

Mariam would always remember Nana the way she looked on Ration Day: a tall, bony, barefoot woman leaning in the doorway, her lazy eye narrowed to a slit, arms crossed in a defiant and mocking way. Her short-cropped, sunlit hair would be uncovered and uncombed. She would wear an ill-fitting gray shirt buttoned to the throat. The pockets were filled with walnut-sized rocks. (Hosseini 2008: 14)

It is hard to imagine that the two descriptions above are of the same woman. It is even more difficult to distinguish in which case Nana shows her true self and in which she pretends. It is possible to suggest that these are two different sides of her character and she displays the one that will serve her present purpose best.

Nana uses tricks and lies to achieve her goals. When Jalil mentions that Nargis, his youngest wife, is expecting a child, Nana asks him, "How many is that for you, now? Ten, is it, mashallah ${ }^{5}$ ? Ten?" Jalil answers that she is right and Nana accentuates his mistake: "Eleven, if you count Mariam, of course" (Hosseini 2008: 22). Nana tricks Jalil into admitting that he does not count Mariam as one of his children to demonstrate his true feelings towards her. Moreover, Nana manipulates and lies to Mariam to prevent her from going to Herat. First, she mocks Mariam and her delusions of Jalil. Then, she tries to make Mariam guilty and threatens to die if she goes to Herat. Finally, she manipulates Mariam by telling her that she does this because of her love towards Mariam. By this time, however, Mariam is already tired of Nana's manipulations and understands the motivation behind her mother's words:

If she could articulate it, she might have said to Nana that she was tired of being an instrument, of being lied to, laid claim to, used. That she was sick of Nana twisting the truths of their life and making her, Mariam, another of her grievances against the world. (Hosseini 2008: 28)

5 Arabic. Literally: "Whatever God has willed." Used to express appreciation or joy if something good has happened. 
RÜSSE, KRASNOVA

Mariam. Mariam has existed outside society since her birth. She is called a harami $^{6}$ even by her own mother. This fact makes Mariam an outcast and for the first fifteen years of her life she does not leave the clearing on which her house stands. The circumstances of her birth influence Mariam's life until her death. Her journey towards becoming a trickstar begins with her walk to Herat on her fifteenth birthday. Tired of waiting for Jalil, who promised to take her to the cinema, Mariam crosses the stream that isolates the clearing and heads for Herat. By crossing the stream, she simultaneously crosses a metaphorical line from one world to another. She fearlessly leaves her house, her mother, and her old way of life in hope of a better future: "She gave herself over to the new life that awaited her in this city, a life with a father, with sisters and brothers, a life in which she would love and be loved back, without reservation or agenda, without shame" (Hosseini 2008: 30).

In this episode, Mariam acts as a trickster because she crosses the boundary set by society. As a harami, she is expected to be satisfied with her isolated way of life, the constant absence of her father and with him being ashamed of her. As an Afghan woman, she is supposed to be at home and to obey her father and she is not allowed to travel far from home without a male relative. However, Mariam pays no attention to social restrictions and is able to abandon them to pursue her goal.

The same day that she leaves for Herat, Mariam tricks a man for the first time. When nobody allows her to enter Jalil's house, Mariam spends the night in the street near the gates and is awakened in the morning by the driver, who orders her to sit in the car so he can drive her back home. Mariam pretends to walk to the car, but then changes the direction and runs through the gates to Jalil's house. The driver is not able to stop her.

Mariam uses tricks and lies to Rasheed (an old man she is forced to marry by Jalil's family) to gain some power and influence in their marriage. When they first arrive at Rasheed's house, he asks Mariam whether she is afraid of him, and she hears something playful in his words, so she lies: "She quickly shook her head in what she recognized as her first lie in their marriage" (Hosseini 2008: 59).

The final trick that Mariam plays on Rasheed is his murder. It is not a common way for the trickstar to behave, but Mariam has no other means to fight the injustice in that situation. As Rasheed is determined to kill Laila, his second wife, for having a conversation with Tariq, she is forced to resort to extreme measures in order to stop him, so she hits his head with a shovel.

6 Farsi: bastard. 
Surprisingly, Mariam is able to ridicule Rasheed at this moment as she thinks that "maybe she had quite literally knocked some understanding into his head." Mariam kills Rasheed because she understands that if she does not do what she needs to do, he will finally kill them. It is not fear for her own life that urges Mariam to make the decision, but it is fear for Laila's life: "Had Mariam been certain that he would be satisfied with shooting only her, that there was a chance he would spare Laila, she might have dropped the shovel. But in Rasheed's eyes she saw murder for them both" (Hosseini 2008: 340).

At this point of her life, Mariam feels that it is the first time that she decides "the course of her own life" (Hosseini 2008: 341). Mariam knows that the Taliban will eventually discover Rasheed's body and will look for them to punish them for the murder, so she protects her loved ones one more time and stays at home. Mariam is ready to sacrifice her own life in order to save the innocent. As Mariam is being led to the stadium to receive her death penalty, she finally feels at peace: "[...] it was not regret any longer but a sensation of abundant peace that washed over her." The reason is the fact that after living all her life as a prisoner of men's decisions, she, at last, is the master of her own life. “'Kneel,' the Talib said. [...] 'Kneel here, hamshira7. And look down.' One last time, Mariam did as she was told” (Hosseini 2008: 361).

Both Mariam and Laila are constantly "on the road." "The road that trickster travels is a spirit road as well as a road in fact” (Hyde 1998: 13). They travel from city to city and even from country to country. Mariam's physical journey starts in a kolba outside Herat. She travels to Herat and returns to the kolba only to discover that she cannot stay there any longer. She travels back to Herat and then goes to Kabul with Rasheed, but neither of these places becomes her home. Mariam's physical journey is finished only with her death. Laila does not feel at home in her own house because of the atmosphere of hostility between her parents, so she attends every lunch at Tariq's house in order to feel part of the family. However, she does not have the chance to become a real member of the family and is forced to move into Rasheed's house instead. Later she lives with Tariq in Murree, Pakistan, and even though everything seems perfect, Laila still does not feel at home and returns to Kabul after the end of the war.

Laila. Laila's early years are different from and at the same time similar to Mariam's. She is born a legitimate child and has both parents, but is deprived of motherly love and attention for the most part of her life. She is educated and beautiful, has close friends, but this does not help her later in life as she becomes

Farsi: sister. 
RÜSSE, KRASNOVA

an orphan at fourteen, loses all her friends, and has to marry Rasheed. The turning point of Laila's life and the beginning of her way to become a trickstar is the moment she decides to overcome social limitations and takes further her relationship with Tariq, her childhood friend. As she turns fourteen, her friendship with Tariq becomes condemned by the neighbourhood, but Laila chooses to disregard their gossip. Later, Laila transgresses the boundaries set by Afghan society when she lets a man who is not her husband kiss her. She goes even further and, when Tariq tells her that he is leaving Afghanistan with his parents, loses her virginity to him. By doing so Laila breaks the boundaries and this action defines her future life.

Laila's parents die in a rocket attack, and Rasheed saves her from the ruins of their house and takes care of her at her home. He hires a man to come and tell Laila that Tariq has died to force her to stay with him. Laila is thinking of leaving Rasheed's house, but discovers that she is pregnant with Tariq's child, so when Rasheed proposes to her, she immediately agrees. Rasheed thinks that he tricked Laila into marrying him, but it is actually Laila who tricks Rasheed to protect her child. Laila tricks her husband again on their wedding night to conceal the fact that she is not a virgin:

Later, when she was sure that he was asleep, Laila quietly reached beneath the mattress for the knife she had hidden there earlier. With it, she punctured the pad of her index finger. Then she lifted the blanket and let her finger bleed on the sheets where they had lain together. (Hosseini 2008: 214)

Laila continues to trick Rasheed as she steals money from him and plans to run away: "Every week, since Aziza's birth, she pried his wallet open when he was asleep or in the outhouse and took a single bill" (Hosseini 2008: 241). She takes smaller bills if the wallet is light and bigger if it is full. Rasheed never notices that some money is missing. Laila tricks not only her husband but also the Taliban guards. When she is forced to bring Aziza to an orphanage in order to save her from hunger, Laila goes to see her every day. However, when Rasheed refuses to accompany her, she persists in her daily walks even though it is forbidden for women to walk alone under Taliban rule. Half of the time she is stopped and forced to return home, but Laila refuses "to cave in." "She made as if she were going home, then took a different route down side streets" (Hosseini 2008: 313). To avoid being hurt by the Talibs, she starts to wear extra layers of clothes under her burqa even in the heat. This way she can endure their lashings. 
Laila has a good sense of humour that she manages to preserve even in such harsh circumstances. When Laila just marries Rasheed, he compares her to Mariam and tells them that if they were cars, Mariam would be a Volga and Laila would be a Benz. After it becomes evident that Laila is pregnant, Mariam teases her and Laila attempts to lighten the mood:

"I can't imagine what you are now," Mariam said, picking grains of rice and bread crumbs, "if you were a Benz before." Laila tried a more lighthearted tactic. "A train? Maybe a big jumbo jet." (Hosseini 2008: 222)

By assuming the role of trickstar a woman "may seek to avoid sex altogether, desiring a free and independent existence" (Jurich 1998: 30). Both Laila and Mariam try to avoid sex with their husband. After the birth of Aziza, her first child, Laila refuses to have intimacy with Rasheed until she is forced to surrender by Rasheed threatening Mariam because he suspects that she teaches Laila to deny him. Laila is a trickstar because she wants to control her intimacy with Rasheed and "desires sexual pleasure from a single man she selects as her own and one who eagerly returns her affection" (Jurich 1998: 30). Laila chooses Tariq as her partner and, consequently, nothing can stop her from having intimacy with him outside her marriage and, later, from meeting him in secret.

Laila is not able to live a peaceful and meaningful life in Pakistan when there are people struggling to return to Kabul after the war. She feels the urge to do something important, to contribute to the changes happening in Afghanistan.

She has become plagued by restlessness. She hears of schools built in Kabul, roads repaved, women returning to work, and her life here, pleasant as it is, grateful as she is for it, seems [...] insufficient to her. Inconsequential. Worse yet, wasteful. (Hosseini 2008: 378)

Laila's motive intersects with that of a pro-social trickstar, whose goal is "that order is restored and justice served" (Mills 2011: 58).

\section{Features of Afghan Storytelling in A Thousand Splendid Suns}

Distinctive traits of Afghan storytelling are gender-centring, portrayal of female characters as tricksters, and the journey made by the heroine in order to become a trickstar (Andrews 2016: 8). All these three techniques are present in A Thousand Splendid Suns. First of all, Hosseini uses gender-specific 
protagonists to illustrate the lives of Afghan women. The main characters are all female. He employs this technique in The Kite Runner as well, but with all the main characters being male.

Secondly, the majority of Hosseini's female characters use trickery and manipulation to gain power or to stop injustice and have other distinctive features of the trickstar. In the previous subchapters, only the three main characters are discussed, but some of the secondary ones resort to trickery and manipulation as well. For instance, Laila's classmate and friend Hasina laughs at life's injustices and gives an ironic nickname to their teacher:

The teacher's name was Shanzai, but, behind her back, the students called her Khala Rangmaal, Auntie Painter, referring to the motion she favored when she slapped students - palm, then back of the hand, back and forth, like a painter working a brush. (Hosseini 2008: 111)

Hasina is said to excel in mischief and wit to compensate for what she lacks "in smarts." It is she who suggests to her friends a way to discourage unattractive suitors:

Beans. No less than four cans. On the evening the toothless lizard comes to ask for your hand. But the timing, ladies, the timing is everything. You have to suppress the fireworks 'til it's time to serve him his tea. (Hosseini 2008: 113)

Hasina's advice also serves as an example of scatological humour, which is often found in trickster tales and is used in the folktale "Women's Tricks" as well. Another parallel with "Women's Tricks" is a grotesque description of the oppressor and the use of scatological details. For example, Rasheed is illustrated as a grotesquely huge man. When Mariam first sees him, the size of him terrifies her and the bowl of the table clinks from the heaviness of his steps (Hosseini 2008: 52). On their wedding night, Laila sees his "sagging breasts, his protruding belly button, the small blue vein in the center of it," and this description carries unnecessarily graphic details to inspire disgust (Hosseini 2008: 214). Finally, Rasheed's image when he lies dead on the floor reminds us of the mullah in "Women's Tricks" after his release from the trunk: "He was lying on his back, staring at nothing with an unblinking, fish-mouthed expression. A bit of foam, lightly pink, had dribbled from his mouth down his cheek. The front of his pants was wet" (Hosseini 2008: 343).

Rasheed's murder symbolizes the return of the authority in the house and in their lives back to Mariam and Laila. As in the folktale "Women's Tricks", the trickstars here operate in a domestic environment and overpower the 
unsuspecting male oppressor. Rasheed does not expect his wives to unite against him and thus makes a fatal mistake by underestimating them. Together, they overcome the oppression of their husband and are now free to make their own choices in life. In "Women's Tricks", the trickstar also defeats oppression and defends her right to decide the course of her life.

In both the novel and folktale, trickstars do not destroy patriarchy by eliminating some of its representatives, but rather they improve and transform society to create a more suitable and just form of the social order. In "Women's Tricks", the trickstar's goal is not to become the head of the family nor is it to have more power than the husband in general, but it is only to defend her authority inside the house. In A Thousand Splendid Suns Laila and Mariam do not wish to do away with patriarchy either. It is the misogynistic and oppressive social order enforced by Rasheed and the Taliban that needs to be destroyed.

\section{Conclusion}

Numerous similarities can be established between the traditional Afghan trickstar and female characters of Hosseini's novel A Thousand Splendid Suns. Hosseini's heroines are trickstars because they:

1) Use tricks and lie in order to achieve their goals

2) Exist on the outskirts of society

3) Aim at uncovering bigotry of male authorities

4) Cross the boundaries set by society

5) Resort to shapeshifting

6) Use their sexual powers to control men

All of these qualities of a trickstar are to some extent present in the heroines analysed in this essay. All three of them experience isolation from society, break the boundaries, trick and uncover hypocrisy of the authorities. Nana is able to change her appearance and behaviour according to her goals, and both Mariam and Laila control the extent of intimacy with their husband.

Furthermore, some of the characters from A Thousand Splendid Suns display distinct qualities of the Afghan pro-social trickstar. Both Mariam and Laila are pro-social trickstars as they:

1) Operate in a domestic environment

2) Perform tricks to fight injustice

3) Re-establish a semblance of patriarchal social order

These three qualities are present both in the heroine of the folktale "Women's Tricks" and in Mariam, Laila, and (to a lesser extent) Nana from Hosseini's novel. Their house is the place of power for them and the majority of the tricks 
RÜSSE, KRASNOVA

they perform take place in a domestic environment. The trickstar in "Women's Tricks" protects her home and fights to gain authority there. Similarly, Mariam and Laila pull their tricks under the roof of Rashid's house without him noticing it. Mariam and Laila are forced to resort to trickery because the power is in the hands of undeserving males who oppress and cause injustice. However, the result of their actions is not the elimination of patriarchy but only its transformation.

In addition to trickstar characters, Hosseini employs other techniques of traditional Afghan storytelling such as the use of scatological or sexual humour, gender-centring, and the journey that characters make to become trickstars. Scatological humour is used to undermine the authority and respectability of males both in "Women's Tricks" and in A Thousand Splendid Suns. Gendercentring is obvious in Hosseini's novel, as all the main characters are female and they all are forced to be constantly "on the road" until they finally gain freedom to decide the course of their lives and achieve peace.

Considering all the similarities between the Afghan folktale trickstar and heroines in Hosseini's novel, it is possible to suggest that the oral culture of Afghanistan has greatly influenced the author's writing. Afghan women in $A$ Thousand Splendid Suns are portrayed as trickstars to show the reality of their everyday lives and to reveal the true nature of these women, who are not faceless and voiceless pictures presented by the Western media, but women who fight for their rights and become real-life trickstars in order to survive.

\section{Paul Rüsse \\ paul@tlu.ee}

\section{Anastassia Krasnova}

krasn@tlu.ee

Tallinna Ülikool

Humanitaarteaduste instituut

Narva mnt 25

10120 Tallinn

EESTI / ESTONIA 
Pro-Social Trickstars in Khaled Hosseini's A Thousand Splendid Suns

\section{Works Cited}

Andrews, A. 2016. (Re)Defining Afghan Women Characters as Modern Archetypes Using Khaled Hosseini's A Thousand Splendid Suns and Asne Seierstad's The Bookseller of Kabul. MA Thesis, Liberty University, https://digitalcommons. liberty.edu/masters/402/.

Basso, E. B. 1987. In Favor of Deceit: A Study of Tricksters in an Amazonian Society. Tucson: University of Arizona Press.

Beeman, W. O. 2005. Persian, Dari and Tajik in Central Asia. - National Council for Eurasian and East European Research. University of Pittsburgh, www.ucis.pitt.edu/ nceeer/2005_817_17g_Beeman.pdf.

Burton, R., transl. 1968. The Book of the 1001 Nights. Ed. by P. H. Newby. London: Panther Books.

Cheng, A. 2009. More on Trickster Makes This World. - TED Blog. https://blog.ted. com/trickster_makes/ (09.04.2018).

Hosseini, K. 2003. An Interview with Khaled Hosseini. - https://www.bookbrowse. com/author_interviews/full/index.cfm/author_number/900/khaled-hosseini? (21.08.18).

Hosseini, K. 2008. A Thousand Splendid Suns. London: Bloomsbury.

Hyde, L. 1998. Trickster Makes This World: Mischief, Myth, and Art. New York: North Point Press.

Hynes, W. J.; Doty, W. G., eds. 1993. Mythical Trickster Figures. Tuscaloosa: University of Alabama Press.

Ioannesyan, Y. 2009. Afghan Folktales from Herat: Persian Texts in Transcription and Translation. Amherst: Cambria Press.

Irwin, R. 2003. The Arabian Nights: A Companion. London: Tauris Parke.

Jung, C. G. 1970. Instinct and the Unconscious. - The Structure and Dynamics of the Psyche, translated by R. F. C. Hull, $2^{\text {nd }}$ ed., Princeton UP, 129-138. The Collected Works of C. G. Jung, vol. 8. ProQuest Ebook Central.

Jung, C. G. 1981. On the Psychology of the Trickster-Figure. - The Archetypes and the Collective Unconscious, transl. by R. F. C. Hull, $2^{\text {nd }}$ ed., Princeton UP, 255-272. The Collected Works of C. G. Jung, vol. 9, part 1. ProQuest Ebook Central.

Jurich, M. 1998. Scheherazade's Sisters: Trickster Heroines and Their Stories in World Literature. Westport, CT: Greenwood Press.

Landay, L. 1998. Madcaps, Screwballs, and Con Women: The Female Trickster in American Culture. Philadelphia: University of Pennsylvania Press.

Levine, E. 2009. A Theory of Everything. - https://www.youtube.com/watch?v= grtGI7QpPdw (14.12.2017).

Mills, M. A. 2001. The Gender of the Trick: Female Tricksters and Male Narrators. Asian Folklore Studies, 60.2, 237-258. https://doi.org/10.2307/1179056

Mills, M. A. 2010. Oral and Popular Literature in Dari Persian of Afghanistan. - Ph. G. Kreyenbroek, U. Marzolph, eds., Oral Literature of Iranian Languages: Kurdish, Pashto, Balochi, Ossetic, Persian and Tajik. London: I. B. Tauris, 303-321. 
RÜSSE, KRASNOVA

Mills, M. A. 2011. Between Covered and Covert: Traditions, Stereotypes, and Afghan Women's Agency. - J. Heath, A. Zahedi, eds., Land of the Unconquerable: The Lives of Contemporary Afghan Women. Oakland: University of California Press, 60-73.

Mills, M. A. 2012. Destroying Patriarchy to Save It: Safdár Tavakkolí's Afghan Boxwoman. - K. Turner, P. Greenhill, eds., Transgressive Tales: Queering the Grimms. Detroit: Wayne State University Press, 277-294.

Nicholas, D. A. 2009. The Trickster Revisited: Deception as a Motif in the Pentateuch. New York: Peter Lang Publishing.

Olesen, A. 1995. Islam and Politics in Afghanistan. London: Routledge.

Pourshariati, P. 2008. Decline and Fall of the Sasanian Empire. London: I. B. Tauris.

Qur'an. 2018. - tanzil.net/\#12:28 (20.07.2018).

Radin, P. 1956. The Trickster: A Study in American Indian Mythology. New York: Schocken Books.

Tatar, M. 2014. The Cambridge Companion to Fairy Tales. Cambridge: Cambridge University Press. 